\title{
PERSEPSI SISWA TERHADAP LAYANAN KONTEN DALAM BIMBINGAN DAN KONSELING DI KELAS VIII SMP NEGERI 15 PALEMBANG
}

\author{
Desi Iskandar \\ SMP NEGERI 15 PALEMBANG \\ Email: desiiskandargumay@gmail.com
}

\begin{abstract}
ABSTRAK
Penelitian ini bertujuan untuk mengetahui Persepsi Siswa terhadap Penguasaan Konten dalam bimbingan dan konseling di kelas VIII SMP Negeri 15 Palembang. Populasi penelitian ini adalah siswa kelas VIIII-VIII5 berjumlah 148 siswa. Sampel diambil secara Random dengan jumlah 30 siswa. Selanjutnya metode yang digunakan pada penelitian ini adalah deskriptif kuantitatif. Teknik pengumpulan data menggunakan penyebaran instrumen angket dengan skala likert. Teknik analisis data menggunakan rumus persentase. Pada hasil penelitian ini dapat disimpulkan bahwa persepsi siswa terhadap layanan konten dalam bimbingan dan konseling kelas VIII di SMP Negeri 15 Palembang secara umum dikategorikan dengan kualitas cukup $(77 \%)$.
\end{abstract}

Kata Kunci: Persepsi Siswa Terhadap Layanan Konten

\section{STUDENT PERCEPTIONS OF CONTENT SERVICES IN GUIDANCE AND COUNSELING IN THE VIII GRADE AT COUNTRY JUNIOR HIGH SCHOOL 15 PALEMBANG}

\begin{abstract}
This study aims to determine students' perceptions of content mastery in guidance and counseling in class VIII SMP Negeri 15 Palembang. The population of this study were 148 students of class VIIII-VIII5. Samples were taken randomly with a total of 30 students. Furthermore, the method used in this research is descriptive quantitative. The data collection technique used the distribution of questionnaire instruments with a Likert scale. The data analysis technique uses the percentage formula. From the results of this study it can be concluded that students' perceptions of content services in guidance and counseling class VIII at SMP Negeri 15 Palembang are generally categorized as having sufficient quality (77\%).
\end{abstract}

Keyword: Student Perceptions Of Content Services

\section{PENDAHULUAN}

Pendidikan ialah salah satu instrumen utama dalam membantu meningkatkan potensi yang ada pada anak bangsa yang berkualitas. Berbagai upaya dan partisipasi 
dari keluarga dan masyarakat juga memberikan dukungan untuk mengembangkan potensi dalam pendidikan yang diharapkan dapat memajukan kualitas pendidikan di Indonesia menjadi lebih.

Salah satu upaya yang dilakukan disekolah dalam mengembangkan potensi dan kualitas yang ada pada individu atau siswa dengan upaya diberikan peran dari bimbingan dan konseling yang dimana di dalamnya terdapat layanan, bidang, fungsi, dan lain-lainnya dalam membantu siswa mengembangkan potensinya. Bimbingan dan Konseling merupakan proses bantuan yang diberikan kepada peserta didik/konseli baik itu individu atau kelompok. Agar mampu berkembang secara optimal serta mandiri dalam hubungan pribadi, sosial, belajar dan karir. Dengan berbagai jenis layanan dan kegiatan pendukung sebagai salah satu penunjang sarana dan prasarana dalam bimbingan dan konseling. (Idris Meity H dan Risaldy Sabil, ( 2015: 6). Lalu Susanto Ahmad ( 2018: 6), bimbingan dan konseling adalah proses pendidikan dalam membantu peserta didik dalam meningkatkan kemampuan dan mencapai perkembangan yang optimal dan pemberian bantuan di berikan oleh konselor kepada peserta didik/konseli.

Dalam jurnal Juniyarti Metha dkk (2018 : 94) menjelaskan, layanan penguasaan konten difokuskan pada pribadi yang mandiri,efektif, dan sukses dalam kehidupan mereka sehari-hari. Perkembangan arah melalui kegiatan pembelajaran yang di mana ada kegiatan layanan konseling. Prayitno (2017 : 94) menjelaskan, Layanan penguasaan konten merupakan layanan bantuan kepada individu (sendirisendiri ataupun kelompok atau klasikal) untuk menguasai kemampuan atau kompetensi tertentu. Layanan penguasaan konten membantu individu menguasai aspek-aspek konten tersebut secara terintegrasikan. Pelaksanaan layanan bimbingan dan konseling seharusnya dapat direspon positif oleh siswa karena sangat bermanfaat bagi siswa untuk mengembangkan potensi mereka.

Namun, di beberapa sekolah masih banyak pelaksaanan layanan bimbingan dan konseling yang belum bisa direspon positif baik dari sekolah maupun dari siswa itu sendiri. Sehingga ada anggapan bimbingan dan konseling itu hanya mengatasi perilaku siswa bermasalah, padahal sebenarnya layanan dalam bimbingan dan 
konseling sangat bermanfaat dan bisa mengembangkan kemampuan atau kompetensi tertentu yang terkait dengan konten yang dimaksud.

Dengan adanya layanan bimbingan dan konseling di sekolah sangat membantu siswa dalam memandang atau berpendapat mengenai suatu hal, dan sangat membantu siswa dalam memahami arti pentingnya bimbingan dan konseling dalam upaya membantu siswa dalam mengembangkan potensi dan kemampuan yang ada pada dirinya. Pandangan atau pendapat inilah yang di sebut dengan persepsi yang dimaksudkan siswa dapat memandang dari sudut pandang mereka masing-masing mengenai layanan yang terdapat di bimbingan dan konseling terutama pada layanan penguasaan konten. Rahmad (2003 : 16) menjelaskan, Persepsi adalah penjabaran suatu objek, informasi yang di landasi oleh pengalaman hidup.

Dengan demikian dapat di katakan juga bahwa persepsi merupakan hasil pikiran seseorang dari situasi tertentu. Persepsi adalah pandangan seseorang bagaimana seorang itu mengartikan atau memandang sesuatu (sobur, 2003: 445). Terkadang ada perbedaan pendapat atau pandangan yang terjadi antara siswa dengan teman lainnya bahkan pendapat antara guru dan siswa tersebut yang berbeda. Setiap siswa memiliki sudut pandang atau angapan tersendiri sehingga membedakan persepsi siswa satu dengan siswa lainnya. Walgito (2010: 99) menjelaskan, persepsi adalah diterimanya rangsangan atau stimulus oleh individu melalui indera. Persepsi adalah proses yang menyangkut masuknya pesan atau informasi ke dalam otak manusia. Melalui persepsi manusia terus menerus mengadakan hubungan dengan lingkungannya. Slameto (2010).

Pelaksanaan layanan bimbingan dan konseling di sekolah seharusnya dapat direspon positif oleh siswa karena sangat bermanfaat bagi siswa untuk mengembangkan potensi mereka. Namun, di beberapa sekolah masih banyak pelaksaanan layanan bimbingan dan konseling terutama di layanan penguasaan konten yang belum bisa direspon positif baik dari sekolah maupun dari siswa itu sendiri.

Sehingga ada anggapan bimbingan dan konseling itu hanya mengatasi perilaku siswa bermasalah, padahal sebenarnya layanan dalam bimbingan dan 
konseling sangat bermanfaat dan bisa mengembangkan kemampuan atau kompetensi tertentu yang terkait dengan konten yang dimaksud seperti dalam bidang sosial, karir, pribadi dan belajar. Hasil kunjungan awal peneliti di SMP Negeri 15 Palembang, berdasarkan observasi ada beberapa siswa yangmasih belum mengerti tentang manfaat dari kegiatan layanan bimbingan dan konseling terutama mengenai layanan penguasaan konten. Selain itu juga beberapa siswa menyatakan bahwa bimbingan dan konseling itu bisa membantu siswa dalam menguasai kemampuan dan kompetensi mereka.

\section{LANDASAN TEORI}

Nuryovi, dkk (2017) dengan judul penelitian Persepsi Siswa Tentang Kompetensi Pedagogik dan Kompetensi Kepribadian Guru jenis penelitian yang dipakai adalah metode deskriptif menggunakan pendekatan kuantitatif dengan penelitian survei. Peneliti mengunakan sampel seluruh kelas X dengan jumlah 100 orang dengan teknik sampling jenuh. Instrumen penelitian ini memakai angket yang digunakan untuk mengukur persepsi siswa tentang kompetensi pedagogik dan kompetensi kepribadian guru dan menggunakan skala likert.

Tarmiji, dkk (2016) dengan judul penelitian Persepsi Siswa Terhadap Kesiapan Guru Dalam Proses Pembelajaran jenis penelitian yang digunakan pada penelitian ini ada dua pendekatan yaitu pendekatan kuantitatif dan pendekatan kualitatif. Populasi penelitian ini adalah seluruh siswa kelas VIII yang terbagi dalam tiga kelas berjumlah 87 siswa. Sampel penelitian siswa kelas VIII-2 sebanyak 30 siswa yang dipilih secara acak. Pengumpulan data dilakukan dengan angket dan wawancara. Hasil penelitian menunjukkan bahwa persepsi siswa SMPN 18 Banda Aceh terhadap kesiapan guru dalam proses pembelajaran tergolong positif seperti dalam penyampaian materi, contoh, menjelaskan istilah-istilah, memilih dan menerapkan metode dan sikap guru terhadap siswa.

Penelitian ini mengarahkan kepada sejauh mana Persepsi Siswa Terhadap Layanan Penguasaan Konten Dalam Bimbingan Dan Konseling. 


\section{METODE PENELITIAN}

Metode yang digunakan untuk mendeskripsikan penelitian yang diperoleh dari sampel atau populasi penelitian sebagaimana adanya menggunakan pengolahan statistik Sugiyono (2017:29). Pendekatan penelitian ini menggunakan metode penelitian kuantitatif deskriptif. Metode ini melibatkan data yang akan dianalisis sesuai metode statistik dengan disesuaikan kriteria berupa persentase. Arikunto ( 2010 : 174 ) jika kita akan meneliti sebagian dari populasi, maka penelitian tersebut disebut penelitian sampel. Sampel sebagian atau wakil populasi yang teliti. sampel yang akan diambil pada penelitian ini adalah $25 \%$ dari populasi yang ada, karena jumlah populasi melebihi 100 yaitu 148 siswa. Berarti 20\% X $148=29,6$ dibulatkan menjadi 30 orang/sampel.

Pengumpulan data pada penelitian ini menggunakan angket. Menurut Sudaryono (2017) mengatakan bahwa metode pengumpulan data ialah teknik atau cara-cara yang dapat digunakan oleh peneliti untuk mengumpulkan data, pengumpulan data dalam penelitian dimaksudkan untuk memperoleh bahan-bahan, keterangan, kenyataan-kenyataan, dan informasi yang dapat dipercaya. Untuk memperoleh data yang dimaksudkan tersebut dapat menggunakan Kusioner (Angket). Angket menggunakan Skala Likert, menurut Sukardi (2019 : 97) kuesioner ini juga sering disebut sebagai angket di mana dalam kuesioner tersebut terdapat beberapa macam pertanyaan yang berhubungan erat dengan masalah penelitian yang hendak dipecahkan serta disebarkan ke responden untuk mendapatkan sebuah informasi saat terjun ke lapangan, di deskripsikan menggunakan rumus persentase, Product Moment dengan bantuan program Excel.

\section{HASIL DAN PEMBAHASAN}

\section{HASIL PENELITIAN}

Berdasarkan tabel jawaban rekapitulasi instrumen, maka hasil rata-rata persentase keseluruhan yaitu 77\%. Menurut Ngalim dikategorikan cukup, maka persepsi siswa terhadap layanan konten dalam bimbingan dan konseling di SMP 
Negeri 15 Palembang dapat dikategorikan cukup, artinya siswa sudah mampu memahami pandangannya atau anggapan mengenai layanan konten yang telah diberikan oleh guru bimbingan dan konseling dan sudah direspon positif oleh siswa itu sendiri, walaupun mungkin masih ada beberapa siswa yang masih belum memahami arti dari layanan bimbingan dan konseling tersebut.

\section{PEMBAHASAN}

Berdasarkan data yang didapat dengan hasil instrumen yang terdiri dari 35 butir item pernyataan yang diberikan kepada 30 responden, kemudian dianalisis dengan teknik statistik dan menggunakan rumus persentase untuk mendapatkan gambaran variabel persepsi siswa terhadap layanan konten. Maka persentase yang didapat yaitu $77 \%$ yang dikategorikan sangat baik.

Pada teori-teori bab sebelumnya telah dijelaskan, persepsi merupakan diterimanya rangsangan atau stimulus oleh individu melalui indera atau juga sering disebut sensoris dan menghasilkan pendapat atau tanggapan (Walgito, 2010: 99). Sedangkan parek dalam sobur (2010: 446) merupakan proses menerima, mengorganisasikan, menerjemahkan atau mengartikan, menyeleksi, dan memberikan reaksi kepada stimulus atau rangsangan indera. Dalam jurnal Tarmiji dkk (2016: 45) persepsi merupakan suatu proses yang bersifat kompleks yang menyebabkan seseorang dapat menerima atau meringkas informasi yang diperoleh dari lingkungannya.

Berdasarkan penjabaran di atas maka kaitannya dengan layanan penguasaan konten dalam bimbingan dan konseling, bahwa persepsi memiliki peran yang penting di setiap pengambilan keputusan individu bagaimana individu itu memahami suatu pendapat dan melihat hal yang sama dengan cara yang sama dalam menghasilkan persepsi atau pendapat yang berbeda. Persepsi yang berbeda dari setiap individu itulah yang dapat mempengaruhi anggapan atau pendapat seorang individu dalam menyikapi suatu hal. Anggapan atau pendapat individu yang baik akan menghasilkan persepsi yang baik dan begitu pula sebaliknya persepsi yang kurang baik akan menghasilkan keputusan yang kurang baik atau pendapat yang kurang baik mengenai 
suatu hal. Maka dari pembahasan penjabaran diatas, dapat disimpulkan bahwa semakin baik persepsi siswa maka pelaksanaan kegiatan layanan penguasaan konten dalam bimbingan dan konseling akan semakin baik dan bagus di SMP Negeri 15 Palembang.

\section{KESIMPULAN}

Hasil penelitian yang telah dilakukan dapat ditarik kesimpulan dari hasil pengolahan data menggunakan metode teknik statistik dengan rumus persentase maka diperoleh hasil rata-rata keseluruhan sebesar 77\%. Dengan ini menunjukkan bahwa persepsi siswa terhadap layanan konten dalam bmbingan konseling kelas VIII di SMP Negeri 15 Palembang dikategorikan Sangat Baik.

\section{SARAN}

Sehubungan dengan simpulan di atas maka peneliti memberikan saran sebagai berikut.

\section{Bagi Guru Bimbingan dan Konseling}

Hendaknya guru pembimbing dapat meningkatkan lagi mutu layanan dengan memilih pokok bahasan/materi yang sesuai kebutuhan dengan kondisi saat ini (masa pandemi) yang dibutuhkan siswa. Serta melihat sarana prasarana untuk kebutuhan siswa dimasa sekarang agar bisa membantu dalam menangani permasalahan pada peserta didik, dan membantu meningkatkan kemampuan dan potensinya.

2. Bagi siswa 
Diharapkan peserta didik mampu memahami setiap layanan yang diberikan guru bimbingan dan konseling dalam meningkatkan kemampuan dan potensinya. Serta bisa menyelesaikan permasalahannya secara mandiri.

3. Bagi peneliti

Penelitian ini dapat dijadikan penelitian lanjutan kepada peneliti selanjutnya mengenai persepsi siswa terhadap layanan penguasaan konten dalam bimbingan dan konseling.

\section{DAFTAR PUSTAKA}

Arikunto. 2010. Prosedur Penelitian Suatu Pendekatan Praktik. jakarta: Rineka Cipta.

Juniyarti Metha Eka, Prayitno, Marjohan. 2018. Content Mastery Service : A Help in Related Consulting Problems Students' Learning Activities. International Journal of Research in Counseling and Education, Volume 02 Number 02 ISSN: 2620-5750 (Print) - 2620-5769 (Electronic) DOI: 10.24036/0075za0002, 94 .

Nuryovi, Wiharna Ono dan Sriyono. 2017. Persepsi Siswa Tentang Kompetensi Pedagogik dan Kompetensi Kepribadian Guru. Journal Of Mechanical Engiineering Education, Vol 4 No 2, 219-224.

Prayitno. 2017. Konseling Profesional Yang Berhasil: Layanan dan Kegiatan Pendukung. jakarta: PT. Rajagrafindo Persada.

Purwanto, Ngalim. 2017. Prinsip-Prinsip Dan Teknik Evaluasi Pengajaran. Bandung: PT Remaja Rosdakarya.

Rahmad, J. 2007. Persepsi Dalam Proses Belajar Mengajar. Jakarta: Rajawali Pers.

Sabil Risaldy dan Meity H Idris. 2015. Bimbingan dan Konseling Pada Pendidikan Anak Usia Dini. Jakarta Timur: PT. Luxima Metro Media.

Slameto. 2010. Belajar dan Faktor-faktor yang Mempengaruhinya. Jakarta: Rineka Cipta.

Sobur, Alex. 2010. Psikologi Umum. Bandung: Pustaka Setia.

Sudaryono. 2017. Metodologi Penelitian. Jakarta: Raja Grafindo Persada. 
Sugiyono. 2017. Metode Penelitian Kuantitatif, Kualitatif, dan R\&D. Bandung: Alfabeta.

Sukardi. 2019. Metodologi Penelitian Pendidikan: Kompetensi dan Praktiknya, Edisi Revisi. jakarta: Bumi Aksara.

Susanto Ahmad. 2018. Bimbingan dan Konseling Di Sekolah konsep, teori dan aplikasinya. Jakarta: Prenadamedia Group

Tarmiji dkk. 2016. Persepsi Siswa Terhadap Kesiapan Guru Dalam Proses Pembelajaran. Jurnal Ilmiah Mahasiswa Pendidikan Kewarganegaraan Unsyiah. Volume 1, Nomor 1: 41-48

Walgito Bimo. 2010. Pengantar Psikologi Umum. Yogyakarta: Andi. 